\title{
DEVELOPMENT OF TECHNOLOGICAL SCHEMES FOR CONDUCTING MINE WORKINGS WITH THE USE OF AN ANCHORAGE WITH ALLOWANCE FOR THE STRESSED STATE OF THE ROCK MASSIF
}

\author{
Alexander Tomilov*, Nadezhda Tomilova, Assiya Batyrkhanova \\ Karaganda State Technical University, 100027, Karaganda, Kazakhstan
}

\begin{abstract}
The article presents a structural scheme for solving the problem of creating a highly effective technology for conducting and supporting preparatory workings, consisting in establishing the laws governing the development of geo mechanical processes for the development of rational technological schemes for conducting mine workings with anchorage. The order of development of technological schemes of carrying out of mine workings with application of an anchor fastening taking into account the intense condition of a file of rocks is generated.
\end{abstract}

\section{Introduction}

Anchor fasteners are used in all countries of the world with a developed mining industry, in France, England, Spain, Kazakhstan, etc. This support is used in a wide range of fastening of preparatory, opening and other excavations.

The main task of the anchorage system is to mobilize and preserve the strength inherent in this array, so that it becomes self-sustaining. The conceptual model of the classifier of an anchoring system for mine workings is shown in Figure 1.

The mine workings in which the anchor bolt is installed in integration with frame supports are less costly compared to the workings, which are fixed only by frames (Table 1) [1].

Table 1. Maintenance costs of mine workings.

\begin{tabular}{|l|c|c|}
\hline $\begin{array}{c}\text { Costs to maintain one kilometer of mine } \\
\text { workings, people / shifts. }\end{array}$ & \multicolumn{2}{|c|}{ Mine, Karaganda } \\
\hline Type of fasteners & Kostenko Mine & Baizhanov Mine \\
\hline Metal & 1962 & 1510 \\
\hline Prefabricated reinforced concrete & 2411 & 13164 \\
\hline Anchor, in integration with the frame & 1133 & 1261 \\
\hline Anchorage & 37 & - \\
\hline
\end{tabular}

\footnotetext{
*Corresponding author: tomilova@kstu.kz
} 
The introduction of a rectangular section of the preparatory excavations with an anchor support guarantees the probability of installing a mechanized lava mount, namely, in the conveyor and ventilation workings, which actually allows to abandon the complicated circuits of movement of sections on the end sections of the lava and to perform these operations without downtime.

The use of anchor bolts in mines of states with a developed coal mining industry allowed to reduce the consumption of metal, concrete and timber $5 \ldots 10$ times; in $3 \ldots 5$ times to increase productivity of work at fastening of developments; 2 ...3 times increase the rate of penetration; to halve the cost of fastening and maintaining the support in working condition during operation.

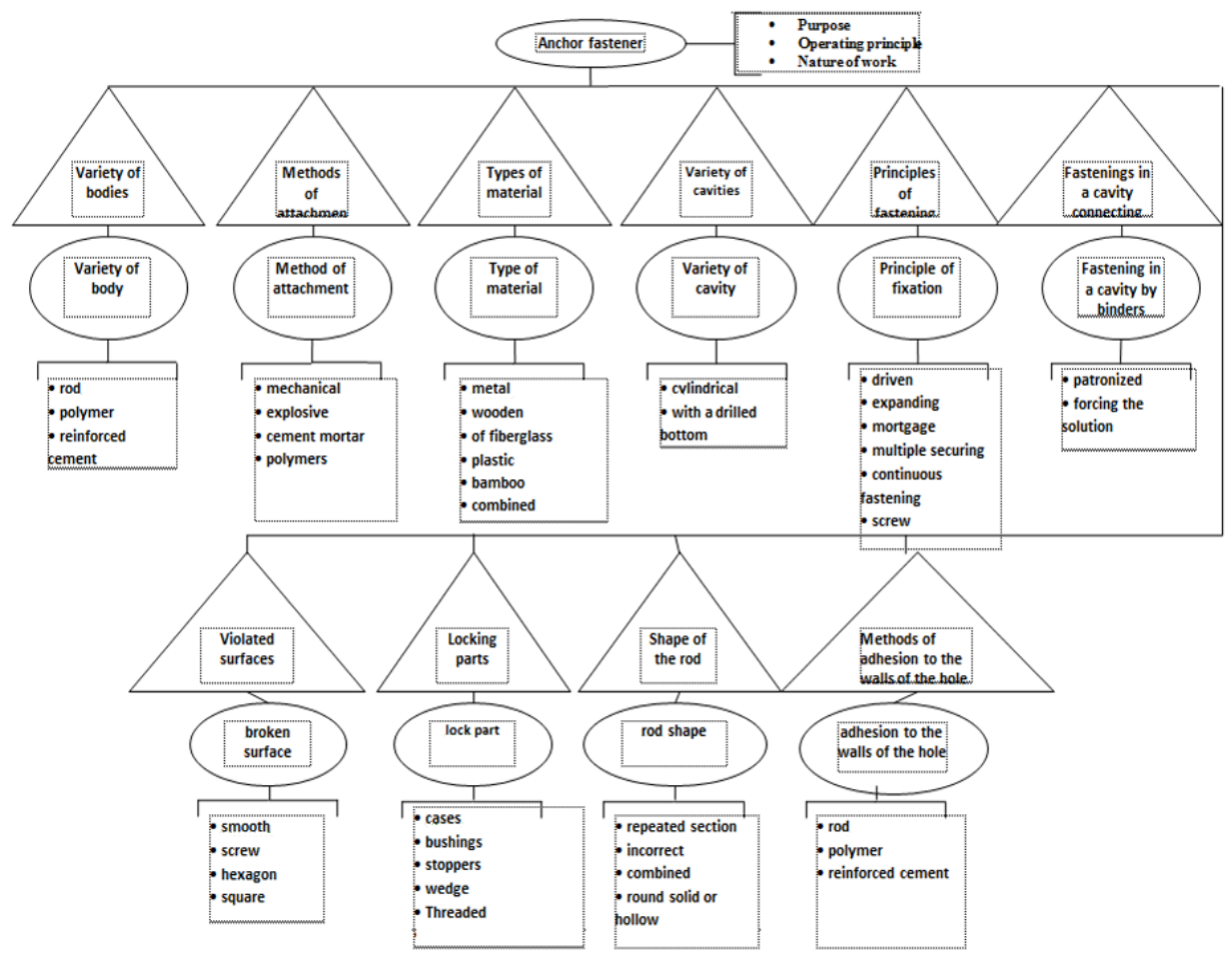

Fig. 1. Conceptual model of the anchorage system classifier.

\section{Methods of solution}

In connection with the complication of mining and geological conditions and increasing the depth of development in the creation of modern technological schemes for conducting mine workings with anchorage, a comprehensive approach combining the study of the stress-strain state of the rock massif and the synthesis of the optimal components of the subsystem "mining and preparatory work" was applied.

The experience of using anchor support in France, England, USA, Germany, Japan has shown that the main directions of improving the anchor support are: increasing the bearing capacity of the anchor, reducing the duration of the installation of anchors and reducing the cost of anchorage.

Not paying attention to the fact that the installation of the anchor support requires less time than the installation of the arch support, in itself, this operation is considered to be the longest 
in the run-through cycle, the utilization factor of the short-cutter takes $20-30 \%$ of the working time. To increase the productive time of the road headers, a systemic approach is required, in which the processes of coal and rock breaking in the face, fixing, ventilation, transportation, auxiliary operations, supplies of materials must be optimized in accordance with the productivity of the equipment used.

For this, a "tree" of variants of qualitative characteristics and quantitative parameters of mining preparatory work is formed on the basis of establishing ranges and steps of changing the dimensions of mine workings, their elements, number, length, speed of advancement of bottom faces, etc.

The presentation of the determining factors on the technological scheme of miningpreparatory works is possible in the following form:

$$
T=T 1 \cup T 2 \cup T 3 \cup T 4 \cup T 5 \cup T 6,
$$

where T1-T6 - respectively, the vectors of mining and geological (T1), mining conditions (T2), cost indicators (T3), socio-economic conditions (T4), conditions determining geomechanical features of mining (T5), and the possibility of actual reproduction of the front of clearing works (T6).

The set of initial mining and geological conditions T1 has the form (Table 2) [2]:

$$
\boldsymbol{T 1}=\left(W_{n}, m, \alpha, Y, P, \mathrm{H}_{g}, \mathrm{O}_{\mathrm{B}}, q\right)
$$

\begin{tabular}{|c|c|c|}
\hline Mining-geological conditions & Value ranges & Initial values \\
\hline Formation thickness $(\mathrm{m}), \mathrm{m}$ & $1.2-3.5$ & $1.2 ; 1.5 ; 2 ; 3 ; 3.5$ \\
\hline Angle of fall $(\alpha)$, degree & $0-30$ & $0 ; 3 ; 8 ; 10 ; 15 ; 25 ; 30$ \\
\hline Stability of the roof rock layers $(Y)$ & $\begin{array}{l}\text { From unstable to } \\
\text { sustainable }\end{array}$ & $\begin{array}{c}\text { Unstable }(\mathrm{ky}=3) \\
\text { Medium stability }(\mathrm{ky}=2) \\
\text { Sustainable }(\mathrm{ky}=1)\end{array}$ \\
\hline $\begin{array}{l}\text { Natural gas content of the reservoir }(q) \text {, } \\
\mathrm{m}^{3} / \mathrm{t}\end{array}$ & $0-15$ & $0-15$ \\
\hline Depth of mining $\left(\mathrm{H}_{g}\right), \mathrm{m}$ & $300-1200$ & $300,600,900,1200$ \\
\hline $\begin{array}{l}\text { Danger of formation on spontaneous } \\
\text { combustion of coal }\left(\mathrm{O}_{\mathrm{B}}\right)\end{array}$ & $\begin{array}{l}\text { From dangerous to } \\
\text { non-hazardous }\end{array}$ & $\begin{array}{l}\text { Dangerous }(\mathrm{Cy}=1) ; \\
\text { Not dangerous }(\mathrm{Cy}=2)\end{array}$ \\
\hline Water formation of the formation $\left(W_{n}\right)$ & $0-15$ & $0 ; 15$ \\
\hline $\begin{array}{l}\text { Propensity of the soil rocks of the } \\
\text { formation to pouches }(P)\end{array}$ & $\begin{array}{l}\text { From non-fluffing to } \\
\text { strongly bulging }\end{array}$ & $\begin{array}{c}\text { Non-budding }(\mathrm{ky}=1) \\
\text { Weakly speaking }(\mathrm{ky}=2) \\
\text { Strongly bulging }(\mathrm{ky}=3)\end{array}$ \\
\hline
\end{tabular}

Table 2. Characteristics of mining and geological developments.

The range of qualitative and quantitative parameters of the technological scheme for mining is presented in Table 3.

Table 3. Range of changes in qualitative and quantitative parameters of the technological scheme for mining.

\begin{tabular}{|l|c|}
\hline \multicolumn{1}{|c|}{ Mining and technological conditions } & Value Range \\
\hline Speed of holding, $\mathrm{m} /$ day $(\mathrm{V})$ & $10 \ldots 20$ (up to 50-60) \\
\hline Location relative to the front of the clearing works (Po) & In the zone and outside the zone \\
\hline Scheme of carrying out (C) & Single-Paired \\
\hline The method of conducting (spruv) & Combine \\
\hline Method of attachment (Skr) & Arched, Combined and Anchor \\
\hline The method for transporting the rock mass (Cr) & Conveyors, Trolleys \\
\hline Method of performing special measures (See) & No, There are \\
\hline
\end{tabular}


The vector of mining technological conditions has the form:

$$
T 2=\left(\boldsymbol{L}_{Л}, \boldsymbol{L}_{\mathrm{cT}}, \boldsymbol{X}, \boldsymbol{T}_{\boldsymbol{p}}, \boldsymbol{M}_{\boldsymbol{n}}, \boldsymbol{R}, \boldsymbol{B}\right)
$$

The operating conditions of the anchor support are characterized by the following mining parameters (Table 4), [3].

A methodical approach for the creation of advanced technological schemes for mining workings is presented in Figure 2.

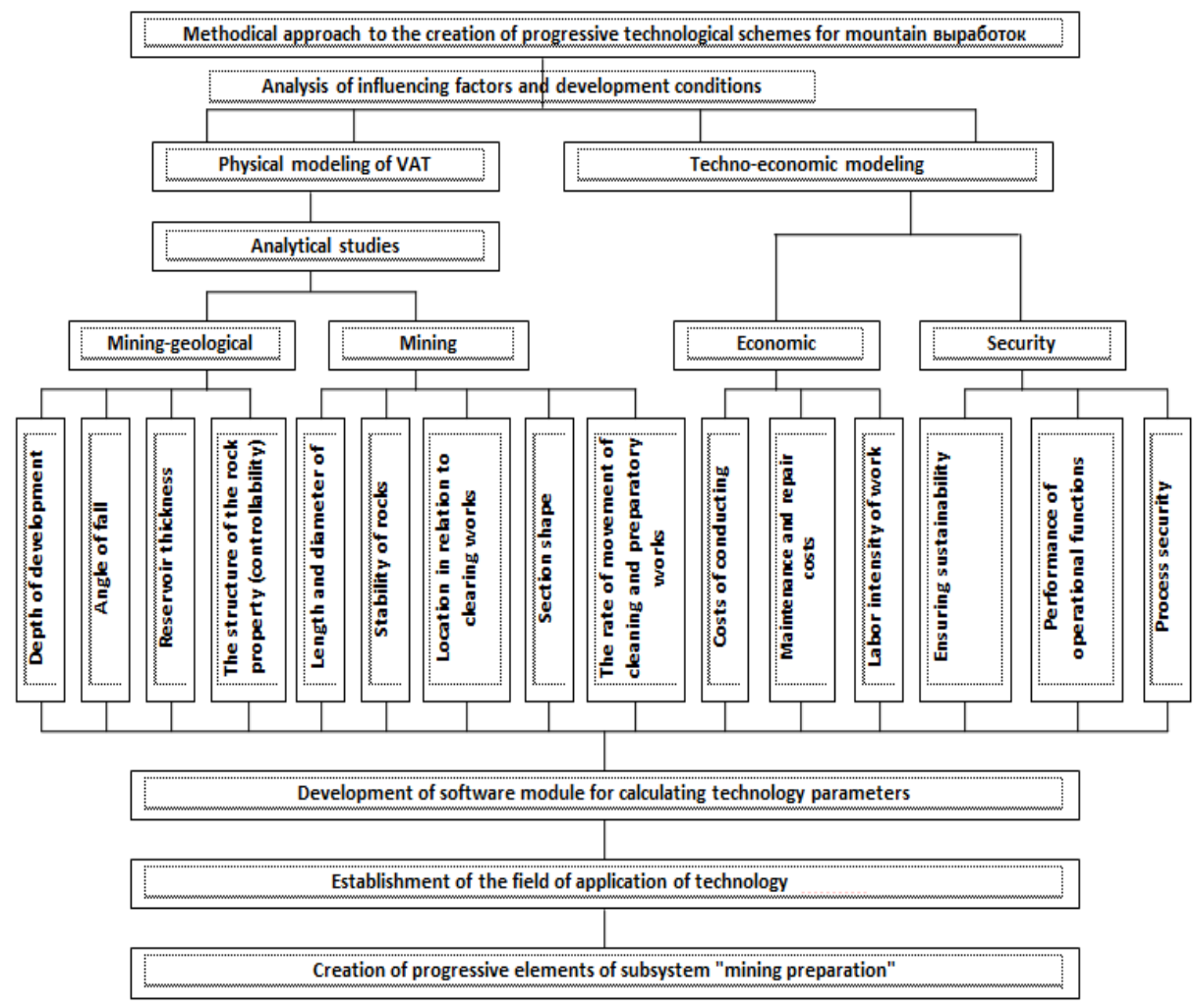

Fig. 2. Solving of the problem of creating progressive technological schemes.

Table 4. Parameters of the use of anchor support in mining technological developments.

\begin{tabular}{|l|c|c|c|c|c|}
\hline \multirow{2}{*}{ Anchor parameters } & \multicolumn{5}{|c|}{ Countries } \\
\cline { 2 - 6 } & \multicolumn{2}{|c|}{ Germany } & England & Australia & USA \\
\hline Diameter, mm & \multicolumn{2}{|c|}{$25-30.4$} & 22 & $19-21$ & $16-19.1$ \\
\hline Length in the rock, $\mathrm{m}$ & \multicolumn{2}{|c|}{$2.1-2.4$} & $2.1-2.3$ & $1.5-2.3$ & $1.4-2.3$ \\
\hline $\begin{array}{l}\text { Estimated load } \\
\text { capacity (kN/anchor) }\end{array}$ & \multicolumn{2}{|c|}{$360-530$} & 310 & $220-320$ & $150-220$ \\
\hline $\begin{array}{l}\text { Section shape of the } \\
\text { output }\end{array}$ & Arched & Rectangular & Rectangular & Rectangular & Rectangular \\
\hline $\begin{array}{l}\text { The density of the } \\
\text { installation (anchor / } \\
\mathrm{m}^{2} \text { ) roof/side }\end{array}$ & $1.0-2.0$ & $1.4-2.2$ & $1.1-3.0$ & $0.5-0.7$ & $0.4-0.7$ \\
\cline { 2 - 6 } & $0.6-1.9$ & $0.5-1.2$ & $0.3-0.9$ & $0.11-0.23$ & $0.09-0.15$ \\
\hline
\end{tabular}




\section{Conclusion}

1) To ensure an effective increase in the volume of mine workings, a methodical approach has been developed to solve the problem of creating a progressive technology for conducting and maintaining preparatory mine workings.

2) To ensure an effective increase in the volume of mine workings, a methodical approach has been developed to solve the problem of creating a progressive technology for conducting and maintaining preparatory mine workings.

3) To ensure the protection and increase the efficiency of underground mining, the main provisions of the underground coal mining technology are formed, based on the improvement of the subsystem of "mining and preparatory work", which consist in finding the patterns of development of geomechanical processes for the development of optimal technological schemes for carrying out mine workings with an anchor fastening.

4) The procedure for the development of technological schemes for conducting mine workings with the use of anchorage was taken into account, taking into account the stressed state of the rock massif:

- Study of regularities of interaction between anchor support and rock massif, with geomechanical processes taking place in host rocks and under the influence of technological factors.

- Determination of the parameters for fixing the mine workings taking into account the impact of mining and time factors.

- Creation of a cadaster model for establishing the area of rational application of anchorage of mine workings and zoning.

- Development of progressive methods and means for attaching control to the state of the array to improve the quality of the strengthened rocks prone to changing mining mining conditions, taking into account the technogenic stress-strain state of the massif.

\section{References}

[1] V. Demin, Proceedings of the Conference Actual problems of the mining and metallurgical complex of Kazakhstan-na-Karaganda, 128 (2017)

[2] Handbook on the securing of capital and preparatory mine workings (Nedra, Moscow, 1982)

[3] Zh Vareha, A Saranchukov, V. Demin, Proceedings of the International Scientific and Practical Conference Actual Problems of the Mining and Metallurgical Complex of Kazakhstan, 102 (2007) 